ISSN 0258-7122

Bangladesh J. Agril. Res. 39(2): 359-371, June 2014

\title{
RESPONSE OF CORIANDER (Coriandrum sativum L.) FOLIAGE TO DIFFERENT RATES AND METHODS OF NITROGEN APPLICATION
}

\author{
M. MONIRUZZAMAN ${ }^{1}$, M. M. RAHMAN ${ }^{2}$, M. M. HOSSAIN ${ }^{3}$ \\ A. J. M. SIRAJUL KARIM ${ }^{4}$ AND Q. A. KHALIQ ${ }^{5}$
}

\begin{abstract}
The experiment was conducted at Bangabandhu Sheikh Mujibur Rahman Agricultural University, Gazipur during January 2009 to February 2009 taking two coriander (Coriandrum sativum L.) lines, CS001 and CS003 to determine the nitrogen requirement of coriander foliage crop and to select the best method of nitrogen application for maximizing foliage yield. The experiment was laid out in randomized complete block design with three replications having five nitrogen doses $(0,20,40,60$, and $80 \mathrm{~kg} / \mathrm{ha})$ and four methods of $\mathrm{N}$ application (entire $\mathrm{N}$ dose as basal, $1 / 2 \mathrm{~N}$ as basal, and $1 / 2 \mathrm{~N}$ at 30 days after sowing as top dressing, $1 / 2 \mathrm{~N}$ as basal and $1 / 2 \mathrm{~N}$ at $30 \mathrm{DAS}$ as foliar spray and $2 / 3 \mathrm{~N}$ at $20 \mathrm{DAS}$, $1 / 3 \mathrm{~N}$ at $30 \mathrm{DAS}$, and $1 / 3 \mathrm{~N}$ at $40 \mathrm{DAS}$ as foliar spray). The nitrogen dose of 80 $\mathrm{kg} / \mathrm{ha}$ and $1 / 2 \mathrm{~N}$ as basal and $1 / 2 \mathrm{~N}$ at 30 days after sowing as top dressing independently gave the maximum plant height, number of leaves/plant, single plant weight, plant weight $/ \mathrm{m}^{2}$, and foliage yield/ha. Nitrogen @ $80 \mathrm{~kg} / \mathrm{ha}$ applied half as basal and half at $30 \mathrm{DAS}$ as top dress produced maximum foliage yield/ha closely followed by $60 \mathrm{~kg}$ and $40 \mathrm{~kg} \mathrm{~N} / \mathrm{ha}$ with the same application method. The highest gross margin was recorded from $80 \mathrm{~kg} \mathrm{~N} / \mathrm{ha}$ applied half as basal and half at 30 DAS as top dress (Tk. 262.705 thousand/ha) followed by 60 $\mathrm{kg} \mathrm{N} /$ ha with the same application method (Tk. 259.529 and Tk. 254.342 thousand/ha, respectively) and these two combinations also gave the highest benefit-cost ratio of 6.90 .
\end{abstract}

Keywords: Nitrogen rate, application method, foliage production, Coriandrum sativum $\mathrm{L}$.

\section{Introduction}

Coriander (Coriandrum sativum L.) is an important culinary herb grown throughout the country for the leaves. For successful crop production, all necessary nutrients must be supplied to the plants judiciously in a sufficient amount. Among different major plant nutrients, nitrogen is required in large amounts by plants because it is a constituent of macromolecules, such as protein. Nitrogen encourages cell elongation, above ground vegetative growth, and imparts green colour of plant leaves (Brady, 1990) and this macronutrient makes the plant leaves succulent and soft. Being a leafy crop, it has a great demand to

\footnotetext{
${ }^{1}$ Senior Scientific Officer, Plant Physiology Section, HRC, Bangladesh Agricultural Research Institute (BARI), Gazipur, ${ }^{2 \& 3}$ Professor, Dept. of Horticulture, Bangabandhu Sheikh Muzibur Rahman Agriculture University (BSMRAU), Salna, Gazipur-1706, ${ }^{4}$ Professor, Dept. of Soil Science, BSMRAU, Salna, Gazipur, ${ }^{5}$ Professor, Dept. of Agronomy, BSMRAU, Salna, Gazipur-1706, Bangladesh.
} 
nitrogenous fertilizer. It is a short duration crop and is generally harvested within 35 to 50 days after sowing (Badgujar et al., 1987; Dhanasekar et al., 2000; Oliveira et al., 2003). Moreover, the nutrients like nitrogen should be applied in optimum dose and proper method in order to reduce nitrogen loss and increase yield and nitrogen use efficiency of the crop (BARC, 2005). The requirement of nitrogen, which varies according to environmental conditions, has to be determined by actual field trial for any particular soil and climate. Side by side method of application of nitrogenous fertilizer has great impact on nitrogen utilization by the crop. Therefore, the present study was undertaken with the following objectives:

1. to determine the nitrogen requirement of coriander foliage crop.

2. to find out the best method of nitrogen application for maximizing foliage yield of coriander.

\section{Materials and Method}

The experiment was conducted at the research farm of the Department of Horticulture, Bangabandhu Sheikh Mujibur Rahman Agricultural University, Gazipur during January 2009 to February 2009. The experiment was conducted taking two previously selected coriander genotypes CS001 and CS003. The soil was clay loam having soil $\mathrm{pH}$ of 5.90 contained $1.91 \%$ organic matter. The total nitrogen, available phosphorus, exchangeable potassium, and exchangeable calcium were $0.0795 \%, 30.77 \mathrm{ppm}, 0.35 \mathrm{meq} / 100 \mathrm{~g}$ soil, and $5.33 \mathrm{meq} / 100 \mathrm{~g}$ soil. The experiment was laid out in RCB design with three replications having five nitrogen doses viz., $0\left(\mathrm{~N}_{0}\right), 20\left(\mathrm{~N}_{1}\right), 40\left(\mathrm{~N}_{2}\right), 60\left(\mathrm{~N}_{3}\right)$, and $80\left(\mathrm{~N}_{4}\right) \mathrm{kg} / \mathrm{ha}$ and four methods of $\mathrm{N}$ application viz., entire $\mathrm{N}$ dose as basal $\left(\mathrm{M}_{1}\right), 1 / 2 \mathrm{~N}$ as basal, and $1 / 2 \mathrm{~N}$ at 30 days after sowing (DAS) as top dressing $\left(\mathrm{M}_{2}\right), 1 / 2 \mathrm{~N}$ as basal and $1 / 2 \mathrm{~N}$ at 30 DAS as foliar spray $\left(\mathrm{M}_{3}\right)$ and1/3 $\mathrm{N}$ at $20 \mathrm{DAS}, 1 / 3 \mathrm{~N}$ at $30 \mathrm{DAS}$, and $1 / 3 \mathrm{~N}$ at 40 DAS as foliar spray $\left(\mathrm{M}_{4}\right)$. The unit plot size was $3 \mathrm{~m} \times 1 \mathrm{~m}\left(3 \mathrm{~m}^{2}\right)$. Total sub-plots were 60 for each genotype (CS001 or CS003). The land was fertilized with 5 tons cowdung, $11 \mathrm{~kg} \mathrm{P}$, and $25 \mathrm{~kg} \mathrm{~K} / \mathrm{ha}$. The entire amount of cowdung, phosphorus from TSP, and potassium from MoP, and $\mathrm{N}$ from urea according to treatment was applied to the soil. The seeds (fruits) were rubbed for separating the two mericarps (seeds) and were soaked in water for 24 hours to enhance germination. Seeds were also treated with Bavistin @ 2g per kg of seeds before sowing.

Seeds were sown on 3 January 2009 @ 40 kg/ha seed. The field was kept weed free. One weeding was done once at 25 days after sowing (DAS). Plant thinning was not done. Two irrigations were given at 20 and 30 DAS. To ensure proper germination and crop stand, small amount of water was applied by watering can just after sowing and continued at three-day intervals upto first irrigation. Harvesting of plants was done by cutting just beneath the soil when a few plants were seen to bolt depending upon the genotypes. 
Relative efficiency of different methods was worked out by polynomial function $y=a+b_{1} x_{1}+b_{2} x_{2} \ldots \ldots \ldots \ldots . . . . b_{i} x_{i}$ after working out response curve $(y=$ $a+b x)$ for each method (Rajput and Singh, 1975).

Data were collected from the inner rows of each plot to avoid the border effect. In each unit plot, 10 plants were selected randomly for recording data on different foliage yield contributing characters viz., plant height $(\mathrm{cm})$, leaves/plant (no.), single plant weight (g) for foliage yield. Plants $/ \mathrm{m}^{2}$ (no.) and plant weight $/ \mathrm{m}^{2}$ were also recorded. Plot yield was converted to per hectare yield.

The gross return, gross margin, and benefit cost ratio (BCR) were calculated on the basis of the market price of coriander and input cost. The data were compiled properly and analyzed statistically by MSTAT Program and mean comparison was done by Duncan's Multiple Range Test (DMRT) at 5\% level of probability.

\section{Results and Discussion}

The data have been explained on the basis of individual genotypic response. Under this chapter, only those characters are discussed which were found significant. The non-significant parameters are not discussed although these are incorporated in tables.

All the yield contributing characters except number of plants $/ \mathrm{m}^{2}$ and foliage yield of coriander were significantly affected by various levels of $\mathrm{N}$ and its methods of application (Table 1). Interactions between $\mathrm{N}$ levels and methods of its application had significant positive effect on plant height, single plant weight, foliage weight $/ \mathrm{m}^{2}$, and fresh foliage yield except number of leaves/plant and number of plants $/ \mathrm{m}^{2}$ (Table 1).

Plant height: Plant height of the genotype CS001 increased significantly with the increase of $\mathrm{N}$ up to $80 \mathrm{~kg} / \mathrm{ha}$, while in CS003 plant height significantly increased up to $60 \mathrm{~kg} \mathrm{~N} / \mathrm{ha}$ (Table 1). The maximum plant height $(21.06 \mathrm{~cm}$ and $22.51 \mathrm{~cm}$ for CS001 and CS003, respectively) was recorded from the application of $80 \mathrm{~kg} \mathrm{~N} / \mathrm{ha}$, being closely followed by $60 \mathrm{~kg} \mathrm{~N} / \mathrm{ha}$ in CS003 only. The results are in close conformity with the results of Oliveira et al. (2003).

One-half $\mathrm{N}$ applied at basal and the rest one-half at 30 days after sowing (DAS) $\left(\mathrm{M}_{2}\right)$ maintained a lead over other methods of application in respect of plant height (Table 2). The application of one half of $\mathrm{N}$ at basal and one-half at 30 DAS as top dress $\left(\mathrm{M}_{2}\right)$ gave maximum plant height for CS001 $(17.92 \mathrm{~cm}$ and $19.87 \mathrm{~cm})$ followed by the application of entire $\mathrm{N}$ as basal $\left(\mathrm{M}_{1}\right)(17.34 \mathrm{~cm}$ and $18.92 \mathrm{~cm}$ for CS001 and CS002, respectively). The lowest plant height in both the genotypes was obtained from the application of $\mathrm{N}$ one-third at 20 DAS, onethird at $30 \mathrm{DAS}$, and one-third at 40 DAS as foliar application $\left(\mathrm{M}_{4}\right)$. 
Table 1. Effect of rates and methods of nitrogen application on the yield components and foliage yield of coriander.

\begin{tabular}{|c|c|c|c|c|c|c|}
\hline \multirow{2}{*}{ Treatments } & \multicolumn{2}{|c|}{ Plant height $(\mathrm{cm})$} & \multicolumn{2}{|c|}{ Leaves/plant } & \multicolumn{2}{|c|}{ Plants $/ \mathrm{m}^{2}$} \\
\hline & CS001 & CS003 & CS001 & CS003 & CS001 & CS003 \\
\hline \multicolumn{7}{|l|}{ Nitrogen $(\mathbf{N})$} \\
\hline $\mathrm{N}_{0}$ & $10.65 \mathrm{e}$ & $11.51 \mathrm{~d}$ & $5.43 \mathrm{c}$ & $5.80 \mathrm{c}$ & 464.0 & 420.0 \\
\hline $\mathrm{N}_{1}$ & $14.69 \mathrm{~d}$ & $16.40 \mathrm{c}$ & $6.34 \mathrm{~b}$ & $8.10 \mathrm{~b}$ & 463.0 & 421.0 \\
\hline $\mathrm{N}_{2}$ & $17.39 \mathrm{c}$ & $19.47 \mathrm{~b}$ & $8.06 \mathrm{a}$ & $8.42 \mathrm{a}$ & 465.0 & 420.0 \\
\hline $\mathrm{N}_{3}$ & $19.99 \mathrm{~b}$ & $22.16 \mathrm{a}$ & $8.06 \mathrm{a}$ & $8.61 \mathrm{a}$ & 460.0 & 423.0 \\
\hline $\mathrm{N}_{4}$ & $21.06 \mathrm{a}$ & $22.51 \mathrm{a}$ & $8.21 \mathrm{a}$ & $8.72 \mathrm{a}$ & 464.0 & 419.0 \\
\hline \multicolumn{7}{|c|}{ Method of $\mathrm{N}$ application (M) } \\
\hline $\mathrm{M}_{1}$ & $17.34 \mathrm{~b}$ & $18.92 \mathrm{~b}$ & $7.39 \mathrm{a}$ & $8.04 \mathrm{a}$ & 463.0 & 419.0 \\
\hline $\mathrm{M}_{2}$ & $17.92 \mathrm{a}$ & $19.87 \mathrm{a}$ & $7.45 \mathrm{a}$ & $8.22 \mathrm{a}$ & 464.0 & 420.0 \\
\hline $\mathrm{M}_{3}$ & $16.51 \mathrm{c}$ & $18.17 \mathrm{~b}$ & $7.33 \mathrm{a}$ & $7.75 \mathrm{~b}$ & 465.0 & 422.0 \\
\hline $\mathrm{M}_{4}$ & $15.26 \mathrm{~d}$ & $16.69 \mathrm{c}$ & $6.78 \mathrm{~b}$ & $7.73 \mathrm{~b}$ & 462.0 & 423.0 \\
\hline $\mathrm{CV}(\%)$ & 4.01 & 5.52 & 3.58 & 5.63 & 3.01 & 3.52 \\
\hline
\end{tabular}

Table 1. Cont'd.

\begin{tabular}{l|c|c|c|c|c|c}
\hline \multirow{2}{*}{ Treatment } & \multicolumn{2}{|c|}{ Plant wt (g) } & \multicolumn{2}{c|}{ Foliage wt $/ \mathrm{m}^{2}(\mathrm{~kg})$} & \multicolumn{2}{c}{ Foliage yield (t/ha) } \\
\cline { 2 - 7 } & CS001 & CS003 & CS001 & CS003 & CS001 & CS003 \\
\hline Nitrogen (N) & & & & & & \\
$\mathrm{N}_{0}$ & $1.01 \mathrm{c}$ & $1.24 \mathrm{c}$ & $0.51 \mathrm{c}$ & $0.49 \mathrm{c}$ & $4.90 \mathrm{c}$ & $4.75 \mathrm{c}$ \\
$\mathrm{N}_{1}$ & $1.38 \mathrm{~b}$ & $1.51 \mathrm{~b}$ & $0.64 \mathrm{~b}$ & $0.64 \mathrm{~b}$ & $6.15 \mathrm{~b}$ & $6.05 \mathrm{~b}$ \\
$\mathrm{~N}_{2}$ & $1.90 \mathrm{a}$ & $2.54 \mathrm{a}$ & $0.88 \mathrm{a}$ & $1 . .05 \mathrm{a}$ & $8.45 \mathrm{a}$ & $10.12 \mathrm{a}$ \\
$\mathrm{N}_{3}$ & $1.93 \mathrm{a}$ & $2.57 \mathrm{a}$ & $0.89 \mathrm{a}$ & $1.07 \mathrm{a}$ & $8.59 \mathrm{a}$ & $10.29 \mathrm{a}$ \\
$\mathrm{N}_{4}$ & $1.96 \mathrm{a}$ & $2.58 \mathrm{a}$ & $0.91 \mathrm{a}$ & $1.07 \mathrm{a}$ & $8.77 \mathrm{a}$ & $10.34 \mathrm{a}$ \\
$\mathrm{Method} \mathrm{of} \mathrm{N}$ application $(\mathbf{M})$ & & & & & \\
$\mathrm{M}_{1}$ & $1.85 \mathrm{~b}$ & $2.11 \mathrm{~b}$ & $0.86 \mathrm{~b}$ & $0.86 \mathrm{~b}$ & $8.27 \mathrm{~b}$ & $8.27 \mathrm{~b}$ \\
$\mathrm{M}_{2}$ & $2.05 \mathrm{a}$ & $2.53 \mathrm{a}$ & $0.95 \mathrm{a}$ & $1.06 \mathrm{a}$ & $9.14 \mathrm{a}$ & $9.62 \mathrm{a}$ \\
$\mathrm{M}_{3}$ & $1.41 \mathrm{c}$ & $1.95 \mathrm{c}$ & $0.65 \mathrm{c}$ & $0.81 \mathrm{~b}$ & $6.18 \mathrm{c}$ & $6.90 \mathrm{c}$ \\
$\mathrm{M}_{4}$ & $1.33 \mathrm{c}$ & $1.77 \mathrm{~d}$ & $0.62 \mathrm{c}$ & $0.74 \mathrm{c}$ & $5.93 \mathrm{c}$ & $6.51 \mathrm{~d}$ \\
\hline \multicolumn{1}{c}{ CV (\%) } & 8.14 & 4.43 & 7.04 & 9.48 & 7.30 & 4.50 \\
\hline
\end{tabular}

Means showing different letters in a column are significantly different at $5 \%$ level of probability by DMRT.

$$
\begin{array}{llll}
\mathrm{N}_{0}=0 \mathrm{~kg} / \mathrm{ha} & \mathrm{N}_{1}=20 \mathrm{~kg} / \mathrm{ha} \quad \mathrm{N}_{2}=40 \mathrm{~kg} / \mathrm{ha} \quad \mathrm{N}_{3}=60 \mathrm{~kg} / \mathrm{ha} \quad \mathrm{N}_{4}=80 \mathrm{~kg} / \mathrm{ha} \\
\begin{array}{clll}
\mathrm{M}_{1}=\text { Entire } \mathrm{N} \text { as } \\
\text { basal }
\end{array} & \mathrm{M}_{2}=1 / 2 \mathrm{~N} \text { as basal and } & \mathrm{M}_{3}=1 / 2 \mathrm{~N} \text { as basal } & \mathrm{M}_{4}=1 / 3 \mathrm{~N} \text { at } 20 \mathrm{DAS}, \\
& 1 / 2 \mathrm{~N} \text { at 30 DAS as top } & \text { and } 1 / 2 \mathrm{~N} \text { at } 30 \mathrm{DAS} & 1 / 3 \mathrm{~N} \text { at } 30 \mathrm{DAS} \text { and } \\
& \text { dressing } & \text { as foliar application } & 1 / 3 \mathrm{~N} \text { at } 40 \text { DAS as } \\
& & \text { foliar application }
\end{array}
$$


The maximum plant height in CS001 was recorded from $\mathrm{N}_{4} \times \mathrm{M}_{2}(22.84 \mathrm{~cm})$. However, plant height in $\mathrm{N}_{4} \times \mathrm{M}_{1}(21.80 \mathrm{~cm}), \mathrm{N}_{2} \times \mathrm{M}_{2}(21.76 \mathrm{~cm})$, and $\mathrm{N}_{3} \times \mathrm{M}_{2}$ $\left(21.75 \mathrm{~cm}\right.$ ) were similar to that of $\mathrm{N}_{4} \times \mathrm{M}_{2}$ (Table 3). CS003 exhibited similar behaviour as that of CS001 regarding plant height. The tallest plant was recorded in $\mathrm{N}_{4} \times \mathrm{M}_{2}(24.62 \mathrm{~cm})$, which was similar to $\mathrm{N}_{2} \times \mathrm{M}_{2}(24.18 \mathrm{~cm}), \mathrm{N}_{3} \times \mathrm{M}_{2}(24.14$ $\mathrm{cm}), \mathrm{N}_{4} \times \mathrm{M}_{1}(23.10 \mathrm{~cm})$ and $\mathrm{N}_{3} \times \mathrm{M}_{1}(22.99 \mathrm{~cm})$. It was clear that $\mathrm{M}_{2}$ method produced the maximum plant height irrespective of nitrogen doses except control. The minimum plant height was noticed in plots where no $\mathrm{N}$ was applied.

Leaves/plant: Number of leaves/plant increased with the increase of $\mathrm{N}$ application dose up to $80 \mathrm{~kg} / \mathrm{ha}$ in both the genotypes (Table 1). The maximum leaves/plant (8.21 for CS001 and 8.72 for CS003) was observed in $80 \mathrm{~kg} \mathrm{~N} / \mathrm{ha}$, being at par with 40 and $60 \mathrm{~kg} \mathrm{~N} / \mathrm{ha}$ in all cases. The minimum number of leaves/plant was found in control $\left(\mathrm{N}_{0}\right)$ treatment in all cases (CS001 and CS003). The results are in agreement with that of Moniruzzaman et al. (2009) where maximum number of leaves/plant was found at the highest dose of $\mathrm{N}$ in 'Bangladhonia' (Eryngium foetidum L.). The maximum leaves/plant (7.45/plant and 8.22/plant) was recorded from two applications of $\mathrm{N}$, one half at basal and the remaining half at 30 DAS as top dress $\left(\mathrm{M}_{2}\right)$, which was similar to the application of entire $\mathrm{N}$ applied as basal $\left(\mathrm{M}_{1}\right)$ and one-half $\mathrm{N}$ applied at basal and the rest one-half at 30 DAS as foliar spray $\left(\mathrm{M}_{3}\right)$ in the genotype CS001 and CS003, respectively (Table 1). In CS001 and CS003, the lowest leaves/plant was observed in $\mathbf{M}_{4}$. The interaction effect on number of leaves/plant was insignificant (Table 2).

Single plant weight: Plant weight increased with increasing rate of $\mathrm{N}$ application up to $80 \mathrm{~kg} / \mathrm{ha}$ in CS001 and CS003 (Table 1). The genotypes CS001 and CS003 produced the mean maximum plant weight, 1.96 and $2.58 \mathrm{~g}$, respectively, when nitrogen was applied @ $80 \mathrm{~kg} / \mathrm{ha}$, which was similar to 40 and $60 \mathrm{~kg} \mathrm{~N} / \mathrm{ha}$ in both the genotypes. This result is in consonance with that of BARI (2010) where maximum individual plant weight (fresh weight/plant) of 'Batishak' was recorded at $80 \mathrm{~kg} \mathrm{~N} / \mathrm{ha}$. Moniruzzaman et al. (2009) also obtained maximum fresh weight/plant from the highest dose of nitrogen in 'Bangladhonia' (Eryngium foetidum L.). In CS001 and CS003, one-half $\mathrm{N}$ at basal and the rest one-half at 30 DAS as top dress $\left(\mathrm{M}_{2}\right)$ gave the maximum single plant weight $(2.05 \mathrm{~g} / \mathrm{plant}$ and $2.53 \mathrm{~g} / \mathrm{plant}$, respectively) followed by the application of entire $\mathrm{N}$ applied as basal $\left(\mathrm{M}_{1}\right)$ and the lowest plant weight (1.33 g/plant) was recorded from the application of one-third $\mathrm{N}$ at $20 \mathrm{DAS}$, one-third at $30 \mathrm{DAS}$, and the rest one-third at 40 DAS as foliar application $\left(\mathrm{M}_{4}\right)$ (Table 2). 
Table 2. Effect of interaction of rates and methods of nitrogen application on the yield components and foliage yield in coriander.

\begin{tabular}{|c|c|c|c|c|c|c|c|}
\hline \multicolumn{2}{|c|}{ Treatment comb. } & \multicolumn{2}{|c|}{ Plant height $(\mathrm{cm})$} & \multicolumn{2}{|c|}{ Leaves/plant } & \multicolumn{2}{|c|}{ Plants $/ \mathrm{m}^{2}$} \\
\hline $\begin{array}{l}\text { Nitrogen } \\
(\mathrm{N})\end{array}$ & $\begin{array}{l}\text { Method } \\
\text { (M) }\end{array}$ & CS001 & $\mathrm{CS} 003$ & CS001 & CSO03 & CS001 & $\mathrm{CS} 003$ \\
\hline \multirow{4}{*}{$\mathrm{N}_{0}$} & $\mathrm{M}_{1}$ & $11.03 \mathrm{i}$ & $11.53 \mathrm{i}$ & 5.33 & 5.67 & 464.0 & 418.0 \\
\hline & $\mathrm{M}_{2}$ & $10.65 \mathrm{i}$ & $11.61 \mathrm{i}$ & 5.19 & 5.80 & 460.0 & 420.0 \\
\hline & $\mathrm{M}_{3}$ & $10.50 \mathrm{i}$ & $11.62 \mathrm{i}$ & 5.20 & 5.73 & 465.0 & 424.0 \\
\hline & $\mathrm{M}_{4}$ & $10.43 \mathrm{i}$ & $11.28 \mathrm{i}$ & 5.33 & 5.99 & 464.0 & 420.0 \\
\hline \multirow{4}{*}{$\mathrm{N}_{1}$} & $\mathrm{M}_{1}$ & $15.05 \mathrm{~g}$ & $16.95 \mathrm{~g}$ & 6.30 & 8.02 & 464.0 & 421.0 \\
\hline & $\mathrm{M}_{2}$ & $15.45 \mathrm{~g}$ & $17.80 \mathrm{fg}$ & 6.70 & 8.30 & 465.0 & 420.0 \\
\hline & $\mathrm{M}_{3}$ & $14.48 \mathrm{gh}$ & $18.10 \mathrm{fg}$ & 6.32 & 8.07 & 461.0 & 424.0 \\
\hline & $\mathrm{M}_{4}$ & $13.75 \mathrm{~h}$ & $14.76 \mathrm{~h}$ & 6.00 & 8.00 & 464.0 & 420.0 \\
\hline \multirow{4}{*}{$\mathrm{N}_{2}$} & $\mathrm{M}_{1}$ & $10.00 \mathrm{ef}$ & $20.00 \mathrm{de}$ & 8.30 & 8.50 & 462.0 & 418.0 \\
\hline & $\mathrm{M}_{2}$ & $21.76 \mathrm{ab}$ & $24.18 \mathrm{a}$ & 8.50 & 8.91 & 466.0 & 422.0 \\
\hline & $\mathrm{M}_{3}$ & $17.17 \mathrm{f}$ & $19.00 \mathrm{ef}$ & 8.17 & 8.20 & 464.0 & 420.0 \\
\hline & $\mathrm{M}_{4}$ & $15.44 \mathrm{~g}$ & $17.70 \mathrm{fg}$ & 7.67 & 8.16 & 460.0 & 423.0 \\
\hline \multirow{4}{*}{$\mathrm{N}_{3}$} & $\mathrm{M}_{1}$ & $20.70 \mathrm{dc}$ & $22.99 \mathrm{abc}$ & 8.00 & 9.00 & 464.0 & 422.0 \\
\hline & $\mathrm{M}_{2}$ & $21.75 \mathrm{ab}$ & $24.14 \mathrm{a}$ & 8.33 & 9.02 & 460.0 & 426.0 \\
\hline & $\mathrm{M}_{3}$ & $19.72 \mathrm{~cd}$ & $21.84 b c$ & 8.50 & 8.25 & 465.0 & 423.0 \\
\hline & $\mathrm{M}_{4}$ & $17.75 \mathrm{ef}$ & $19.65 \mathrm{de}$ & 7.40 & 8.19 & 464.0 & 420.0 \\
\hline \multirow{4}{*}{$\mathrm{N}_{4}$} & $\mathrm{M}_{1}$ & $21.80 \mathrm{ab}$ & $23.10 \mathrm{ab}$ & 8.33 & 9.00 & 461.0 & 425.0 \\
\hline & $\mathrm{M}_{2}$ & $22.84 a$ & $24.62 \mathrm{a}$ & 8.53 & 9.08 & 464.0 & 428.0 \\
\hline & $\mathrm{M}_{3}$ & $10.70 b c$ & $22.27 b c$ & 8.47 & 8.50 & 464.0 & 418.0 \\
\hline & $\mathrm{M}_{4}$ & $18.91 \mathrm{de}$ & $20.04 \mathrm{de}$ & 7.50 & 8.30 & 464.0 & 425.0 \\
\hline $\mathrm{CV}(\%)$ & & 4.01 & 5.52 & 5.63 & 4.74 & 3.01 & 3.52 \\
\hline
\end{tabular}

Means showing different letters in a column are significantly different at $5 \%$ level of probability by DMRT.

\begin{tabular}{|c|c|c|c|}
\hline $\mathrm{N}_{0}=0 \mathrm{~kg} / \mathrm{ha}$ & $\mathrm{N}_{1}=20 \mathrm{~kg} / \mathrm{ha}$ & $\mathrm{N}_{3}=60 \mathrm{~kg}$ & $\mathrm{~N}_{4}=80 \mathrm{~kg} / \mathrm{ha}$ \\
\hline $\begin{array}{c}\mathrm{M}_{1}=\underset{\text { basal }}{\text { Entire } \mathrm{N}} \text { as } \\
\text { basal }\end{array}$ & $\begin{array}{l}\mathrm{M}_{2}=1 / 2 \mathrm{~N} \text { as basal } \\
\text { and } 1 / 2 \mathrm{~N} \text { at } 30 \mathrm{DAS} \\
\text { as top dressing }\end{array}$ & $\begin{array}{l}\mathrm{M}_{3}=1 / 2 \mathrm{~N} \text { as basal } \\
\text { and } 1 / 2 \mathrm{~N} \text { at } 30 \mathrm{DAS} \\
\text { as foliar application }\end{array}$ & $\begin{array}{l}\mathrm{M}_{4}=1 / 3 \mathrm{~N} \text { at } 20 \\
\text { DAS, } 1 / 3 \mathrm{~N} \text { at } 30 \\
\text { DAS and } 1 / 3 \mathrm{~N} \text { at } 40 \\
\text { DAS as foliar } \\
\text { application }\end{array}$ \\
\hline
\end{tabular}


Table 2. Cont'd.

\begin{tabular}{|c|c|c|c|c|c|c|c|}
\hline \multicolumn{2}{|c|}{ Treatment comb. } & \multicolumn{2}{|c|}{ Plant wt (g) } & \multicolumn{2}{|c|}{ Foliage wt $/ \mathrm{m}^{2}(\mathrm{~kg})$} & \multicolumn{2}{|c|}{ Foliage yield ( $\mathrm{t} / \mathrm{ha})$} \\
\hline $\begin{array}{l}\text { Nitrogen } \\
\text { (N) }\end{array}$ & $\begin{array}{l}\text { Method } \\
\text { (M) }\end{array}$ & CS001* & $\mathrm{CS} 003$ & CS001 & $\mathrm{CS} 003$ & CS001 & CS003 \\
\hline \multirow{4}{*}{$\mathrm{N}_{0}$} & $\mathrm{M}_{1}$ & $0.97 \mathrm{~g}$ & $1.45 \mathrm{gh}$ & $0.45 \mathrm{e}$ & $0.51 \mathrm{fg}$ & $4.32 \mathrm{e}$ & $4.90 \mathrm{~h}$ \\
\hline & $\mathrm{M}_{2}$ & $1.14 \mathrm{fg}$ & $1.15 \mathrm{i}$ & $0.53 \mathrm{de}$ & $0.48 \mathrm{~g}$ & $5.05 \mathrm{de}$ & $4.61 \mathrm{~h}$ \\
\hline & $\mathrm{M}_{3}$ & $1.15 f g$ & $1.17 \mathrm{i}$ & $0.54 \mathrm{de}$ & $0.49 \mathrm{fg}$ & $5.15 \mathrm{de}$ & $4.70 \mathrm{~h}$ \\
\hline & $\mathrm{M}_{4}$ & $1.14 \mathrm{fg}$ & $1.19 \mathrm{i}$ & $0.53 \mathrm{de}$ & $0.50 \mathrm{fg}$ & $5.08 \mathrm{de}$ & $4.80 \mathrm{~h}$ \\
\hline \multirow{4}{*}{$\mathrm{N}_{1}$} & $\mathrm{M}_{1}$ & $1.43 \mathrm{de}$ & $1.53 \mathrm{~g}$ & $0.67 \mathrm{c}$ & $0.64 \mathrm{ef}$ & $5.57 \mathrm{c}$ & $6.14 f$ \\
\hline & $\mathrm{M}_{2}$ & $1.56 \mathrm{~d}$ & $1.77 \mathrm{f}$ & $0.71 \mathrm{c}$ & $0.77 \mathrm{de}$ & $6.82 \mathrm{c}$ & $7.10 \mathrm{e}$ \\
\hline & $\mathrm{M}_{3}$ & $1.31 \mathrm{def}$ & $1.43 \mathrm{gh}$ & $0.61 \mathrm{~cd}$ & $0.60 f g$ & $5.85 \mathrm{~cd}$ & $5.76 \mathrm{fg}$ \\
\hline & $\mathrm{M}_{4}$ & $1.21 \mathrm{efg}$ & $1.29 \mathrm{hi}$ & $0.56 \mathrm{~d}$ & $0.54 \mathrm{fg}$ & $5.38 \mathrm{~d}$ & $5.18 \mathrm{gh}$ \\
\hline \multirow{4}{*}{$\mathrm{N}_{2}$} & $\mathrm{M}_{1}$ & $2.22 \mathrm{c}$ & $2.46 \mathrm{bcd}$ & $1.03 \mathrm{~b}$ & $1.03 b c$ & $9.89 \mathrm{~b}$ & $9.89 b c$ \\
\hline & $\mathrm{M}_{2}$ & $2.48 \mathrm{ab}$ & $3.18 \mathrm{a}$ & $1.15 \mathrm{a}$ & $1.33 \mathrm{a}$ & $11.07 \mathrm{a}$ & $12.77 \mathrm{a}$ \\
\hline & $\mathrm{M}_{3}$ & $1.48 \mathrm{~d}$ & $2.41 \mathrm{bcd}$ & $0.69 \mathrm{c}$ & $0.98 b c$ & $6.63 c$ & $9.41 \mathrm{c}$ \\
\hline & $\mathrm{M}_{4}$ & $1.43 \mathrm{de}$ & $2.10 \mathrm{e}$ & $0.66 \mathrm{c}$ & $0.88 \mathrm{~cd}$ & $6.37 \mathrm{c}$ & $8.42 \mathrm{~d}$ \\
\hline \multirow{4}{*}{$\mathrm{N}_{3}$} & $\mathrm{M}_{1}$ & $2.27 b c$ & $2.54 b c$ & $1.05 \mathrm{~b}$ & $1.06 \mathrm{~b}$ & $10.11 b$ & $10.18 b$ \\
\hline & $\mathrm{M}_{2}$ & $2.54 \mathrm{a}$ & $3.25 \mathrm{a}$ & $1.18 \mathrm{a}$ & $1.36 \mathrm{a}$ & $11.33 \mathrm{a}$ & $12.94 \mathrm{a}$ \\
\hline & $\mathrm{M}_{3}$ & $1.49 \mathrm{~d}$ & $2.37 \mathrm{~cd}$ & $0.69 \mathrm{c}$ & $0.99 b c$ & $6.56 c$ & $9.50 \mathrm{c}$ \\
\hline & $\mathrm{M}_{4}$ & $1.44 \mathrm{de}$ & $2.13 \mathrm{e}$ & $0.67 \mathrm{a}$ & $0.89 \mathrm{~cd}$ & $6.37 \mathrm{c}$ & $8.54 \mathrm{~d}$ \\
\hline \multirow{4}{*}{$\mathrm{N}_{4}$} & $\mathrm{M}_{1}$ & $2.36 a b c$ & $2.56 b$ & $1.09 \mathrm{ab}$ & $1.07 \mathrm{~b}$ & $10.50 \mathrm{ab}$ & $10.27 b$ \\
\hline & $\mathrm{M}_{2}$ & $2.54 \mathrm{a}$ & $3.27 \mathrm{a}$ & $1.18 \mathrm{a}$ & $1.37 \mathrm{a}$ & $11.43 \mathrm{a}$ & $13.15 \mathrm{a}$ \\
\hline & $\mathrm{M}_{3}$ & $1.51 \mathrm{~d}$ & $2.36 \mathrm{~d}$ & $0.70 \mathrm{c}$ & $0.99 b c$ & $6.72 \mathrm{c}$ & $9.47 \mathrm{c}$ \\
\hline & $\mathrm{M}_{4}$ & $1.44 \mathrm{de}$ & $2.11 \mathrm{e}$ & $0.67 \mathrm{c}$ & $0.88 \mathrm{~cd}$ & $6.43 c$ & $8.48 \mathrm{~d}$ \\
\hline CV (\%) & & 8.14 & 4.43 & 7.04 & 9.48 & 7.30 & 4.25 \\
\hline
\end{tabular}

Means showing different letters in a column are significantly different at 5\% level of probability by DMRT.

$\mathrm{N}_{0}=0 \mathrm{~kg} / \mathrm{ha} \quad \mathrm{N}_{1}=20 \mathrm{~kg} / \mathrm{ha} \quad \mathrm{N}_{2}=40 \mathrm{~kg} / \mathrm{ha} \quad \mathrm{N}_{3}=60 \mathrm{~kg} / \mathrm{ha} \quad \mathrm{N}_{4}=80 \mathrm{~kg} / \mathrm{ha}$

$\mathrm{M}_{1}=$ Entire $\mathrm{N}$ as $\quad \mathrm{M}_{2}=1 / 2 \mathrm{~N}$ as basal $\quad \mathrm{M}_{3}=1 / 2 \mathrm{~N}$ as basal $\quad \mathrm{M}_{4}=1 / 3 \mathrm{~N}$ at 20

basal and $1 / 2 \mathrm{~N}$ at 30 DAS and $1 / 2 \mathrm{~N}$ at 30 DAS DAS, $1 / 3 \mathrm{~N}$ at 30 as top dressing as foliar application $\quad$ DAS and $1 / 3 \mathrm{~N}$ at 40

DAS as foliar application

Maximum plant weight was recorded from $\mathrm{N}_{4} \times \mathrm{M}_{2}(2.54 \mathrm{~g} / \mathrm{plant})$ and $\mathrm{N}_{3} \times \mathrm{M}_{2}$ (2.54 g/plant), which was similar to $\mathrm{N}_{2} \times \mathrm{M}_{2}(2.48 \mathrm{~g} / \mathrm{plant})$ and $\mathrm{N}_{4} \times \mathrm{M}_{1}(2.36$ g/plant) in CS001 whereas, in CS002 $\mathrm{N}_{4} \times \mathrm{M}_{2}$ combination gave the maximum individual plant weight (3.27 g/plant), which was at par with those of $\mathrm{N}_{3} \times \mathrm{M}_{2}$ 
(3.25 g/plant) and $\mathrm{N}_{2} \times \mathrm{M}_{2}$ (3.18 g/plant) (Table 2). The least single plant weight was observed in $\mathrm{N}_{0} \times \mathrm{M}_{1}$, which was similar to other methods of application with no nitrogen. In respect of individual plant weight, $\mathrm{M}_{2}$ method produced the highest individual plant weight irrespective of different $\mathrm{N}$ rates except control in both the genotypes.

Foliage weight per square meter: The maximum weight of foliage $/ \mathrm{m}^{2}$ was 0.91 $\mathrm{kg}$ for CS001 and $1.07 \mathrm{~kg}$ for CS003 that was recorded from $80 \mathrm{~kg} \mathrm{~N} / \mathrm{ha}$, which was similar to 40 and $60 \mathrm{~kg} \mathrm{~N} / \mathrm{ha}$ for both the genotypes (Table 1). The lowest weight of foliage $/ \mathrm{m}^{2}$ was found from control. This result corroborates the results of Moniruzzaman et al. (2006) and Oliveira et al. (2003). One-half N applied at basal and the rest one-half at $30 \mathrm{DAS}$ as top dress $\left(\mathrm{M}_{2}\right)$ produced the maximum foliage weight, $0.95 \mathrm{~kg} / \mathrm{m}^{2}$ for CS001 and $1.06 \mathrm{~kg} / \mathrm{m}^{2}$ for CS003, respectively, and the lowest $(0.62 \mathrm{~kg})$ was recorded from the application of one-third $\mathrm{N}$ at 20 DAS, one-third at $30 \mathrm{DAS}$, and the rest one-third at $40 \mathrm{DAS}$ as foliar application $\left(\mathrm{M}_{4}\right)$ (Table 1).

The treatment $\mathrm{N}_{4} \times \mathrm{M}_{2}, \mathrm{~N}_{3} \times \mathrm{M}_{2}$, and $\mathrm{N}_{2} \times \mathrm{M}_{2}$ exhibited the best performance in respect of the foliage weight $/ \mathrm{m}^{2}$ of coriander (Table 2). In CS003, the maximum foliage weight $/ \mathrm{m}^{2}$ was obtained from both $\mathrm{N}_{4} \times \mathrm{M}_{2}$ and $\mathrm{N}_{3} \times \mathrm{M}_{2}$, which was similar to $\mathrm{N}_{2} \times \mathrm{M}_{2}$ whereas, in CS003 $\mathrm{N}_{4} \times \mathrm{M}_{2}$ produced the highest weight of foliage/m $(1.37 \mathrm{~kg})$, which was statistically identical to that of $\mathrm{N}_{3} \times \mathrm{M}_{2}(1.36 \mathrm{~kg})$ and $\mathrm{N}_{2} \times \mathrm{M}_{2}$ $(1.33 \mathrm{~kg})$. The subsequent weight of foliage $/ \mathrm{m}^{2}$ was observed in $\mathrm{N}_{4} \times \mathrm{M}_{1}, \mathrm{~N}_{3} \times \mathrm{M}_{1}$, and $\mathrm{N}_{2} \times \mathrm{M}_{1}$ in both the genotypes. The least weight of foliage $/ \mathrm{m}^{2}$ was noticed in control $\mathrm{N}$ treatment irrespective of application methods.

Foliage yield: Fresh foliage yield increased significantly with the increase in nitrogen up to $40 \mathrm{~kg} \mathrm{~N} / \mathrm{ha}$ (Table 1). The maximum foliage yield $(8.77 \mathrm{t} / \mathrm{ha}$ for CS001 and $10.74 \mathrm{t} / \mathrm{ha}$ for CS003) was recorded at $80 \mathrm{~kg} \mathrm{~N} / \mathrm{ha}$, which was similar to 60 and $40 \mathrm{~kg} \mathrm{~N} / \mathrm{ha}$ in both the genotypes. The minimum foliage yield was found in control treatment in all the cases. Application of $\mathrm{N}$ at 80 and $60 \mathrm{~kg} \mathrm{~N} / \mathrm{ha}$ increased foliage yield by only $2.71 \%$ compared to $40 \mathrm{~kg}$ $\mathrm{N} / \mathrm{ha}$. It has been suggested to apply $\mathrm{N} @ 45 \mathrm{~kg}$ ha for foliage yield of coriander (http://www.indianspices.com/html/spicesspfarmcori.html). The result is in agreement with the result of BARI (2010) where it was reported that the maximum fresh yield of Batishak was obtained at $80 \mathrm{~kg} \mathrm{~N} / \mathrm{ha}$ and no significant difference was observed among 40 and $80 \mathrm{~kg} \mathrm{~N} / \mathrm{ha}$. The result is in partial agreement with Moniruzzaman et al. (2009) who found the highest fresh yield of Bangladhonia with the application of the highest dose of nitrogen. 


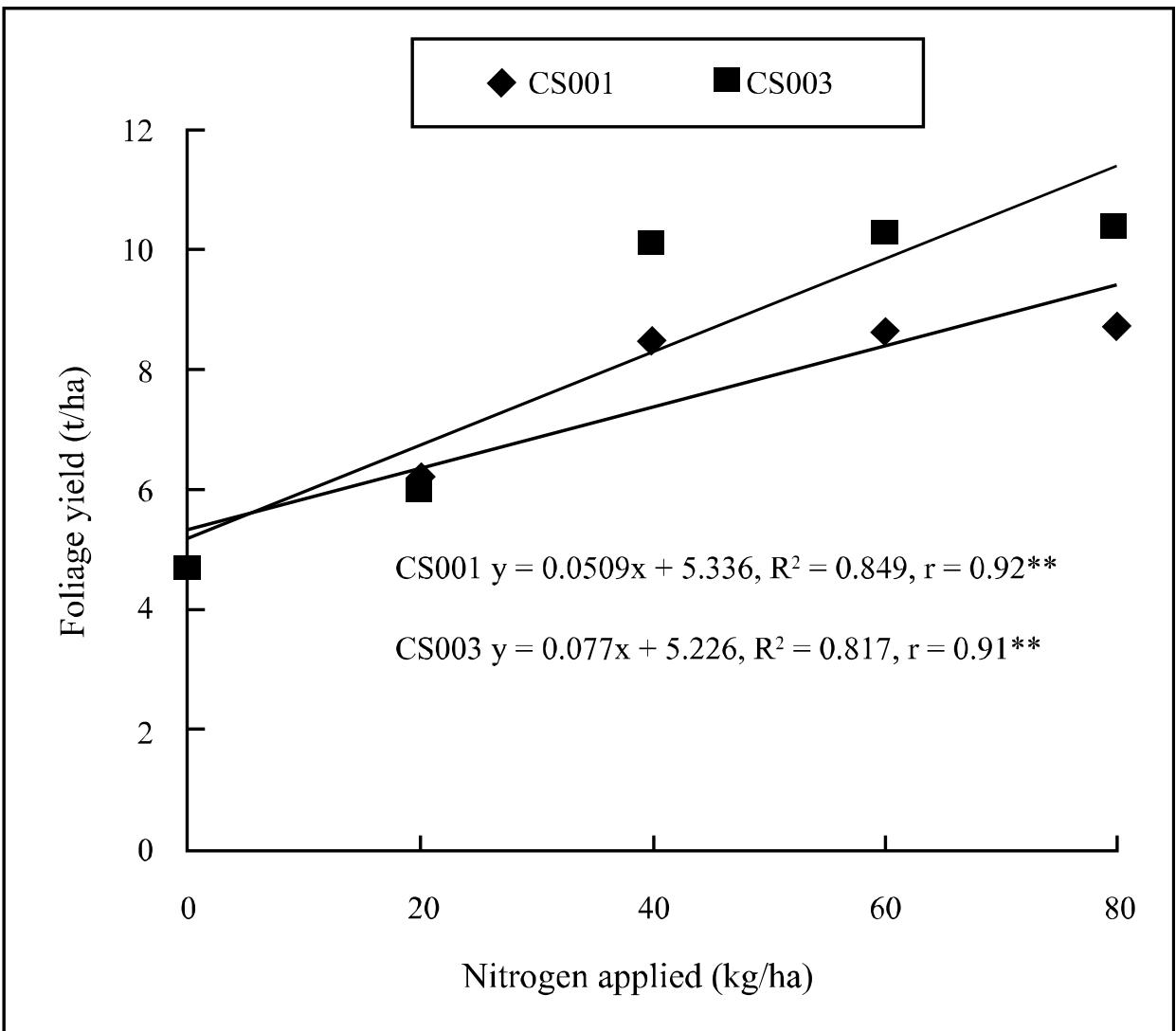

Fig. 1. Relationship between foliage yield and nitrogen levels in coriander.

The foliage yield showed a linear response with increasing levels of nitrogen (Fig. 1). The linear relationships as estimated were $y=0.0509 x+5.336, R^{2}=$ $0.85, \mathrm{r}=0.92 * *$ for CS001, and $\mathrm{y}=0.0777 \mathrm{x}+5.226, \mathrm{R}^{2}=0.82, \mathrm{r}=0.91 * *$ for CS003. The positive relationship indicated that foliage yield increased with the increasing of $\mathrm{N}$ doses for each genotype. The two linear equations stated that for every increased application of $1 \mathrm{~kg} \mathrm{~N} / \mathrm{ha}$ about 50.9 and $77.1 \mathrm{~kg}$ foliage for CS001 and CS003, respectively, were increased per hectare. The $\mathrm{R}^{2}$ values for two genotypes indicated that the 85 and $82 \%$ increase in foliage yield for CS001 and CS003, respectively, was attributed to applied nitrogen. This is in agreement with that of Ullah et al. (1999) who showed that yield response of leafy vegetable, cabbage to applied $\mathrm{N}(0,60,120,180$, and $240 \mathrm{~kg} / \mathrm{ha})$ was linear ( $\mathrm{y}=$ $\left.0.26 \mathrm{~N}+31.5, \mathrm{r}=0.96^{* *}\right)$. Moniruzzaman et al. (2007) obtained the linear yield response of Kangkong to $\mathrm{N}$ application $(\mathrm{y}=0.1195 \mathrm{~N}+40.932, \mathrm{r}=0.97 * *)$. The beneficial effect of $\mathrm{N}$ might be due to the fact that it increases the production of green leaves and the size and chlorophyll content of the leaves which help in the 
synthesis of carbohydrate, protein etc. for building up of new tissues. Eventually, there is an increase in the growth and yield of coriander.

The application of one-half $\mathrm{N}$ at basal and one-half at 30 DAS as top dress $\left(\mathrm{M}_{2}\right)$ gave maximum foliage yield $(9.14 \mathrm{t} / \mathrm{ha}$ for CS001 and $9.62 \mathrm{t} / \mathrm{ha}$ for CS003 and the lowest foliage yield was recorded from $\mathrm{M}_{4}$ (5.93 t/ha for CS001 and $6.51 \mathrm{t} /$ ha for CS003) (Table 2). This is in partial agreement with the report of Moniruzzaman et al. (2005) who found the highest yield of lettuce leaf with split application of nitrogen. The application of entire $\mathrm{N}$ as basal $\left(\mathrm{M}_{1}\right)$ failed to give better result than that of $\mathrm{N}$ one-half at basal and one-half at 30 DAS as top dress $\left(\mathrm{M}_{2}\right)$ due to the fact that coriander was slow in growth in early stage and then rapid growth takes place towards the end of cycle for leaf purpose crop (Oliveira et al., 2003). When $\mathrm{N}$ was applied as basal after 30 days of sowing, effective utilization of $\mathrm{N}$ and rapid vegetative growth took place i.e., maximum plant height and number of leaves/plant are produced. Marked effect of adequate supply of $\mathrm{N}$ by split application at 30 DAS as top dress helped in more and continuous absorption of the same by coriander plants. However, in the present investigation, foliar application of $\mathrm{N}$ by $\mathrm{M}_{3}$ and $\mathrm{M}_{4}$ method might not give fruitful result compared to $\mathrm{M}_{1}$ and $\mathrm{M}_{2}$ due to the fact that leaves of coriander are variously lobed, shiny, and waxy and thus spray $\mathrm{N}$ solution did not stay long enough for activity on the surface of the leaves. In addition, no surfactant was used in spray solution of $\mathrm{N}$. Therefore, split application of $\mathrm{N}$ as top dress showed better performances over basal application $\left(\mathrm{M}_{1}\right)$ and other two methods $\left(\mathrm{M}_{3}\right.$ and $\left.\mathrm{M}_{4}\right)$.

The interactions of $\mathrm{N}$ doses and application methods on foliage yield of coriander were significant and the maximum yield in CS001 was recorded from $\mathrm{N}_{4} \times \mathrm{M}_{2}(11.43 \mathrm{t} / \mathrm{ha})$, which was similar to $\mathrm{N}_{2} \times \mathrm{M}_{2}$ (11.07 t/ha), $\mathrm{N}_{3} \times \mathrm{M}_{2}$ (11.33 $\mathrm{t} / \mathrm{ha}$ ), and $\mathrm{N}_{4} \times \mathrm{M}_{1}(10.50 \mathrm{t} / \mathrm{ha})$ (Table 3$)$. The genotype CS003 gave identical foliage yield, the highest was obtained from $\mathrm{N}_{4} \times \mathrm{M}_{2}(13.15 \mathrm{t} / \mathrm{ha})$, which was similar to $\mathrm{N}_{3} \times \mathrm{M}_{2}(12.94 \mathrm{t} / \mathrm{ha})$ and $\mathrm{N}_{2} \times \mathrm{M}_{2}(11.91 \mathrm{t} / \mathrm{ha})$. The $\mathrm{M}_{\mathrm{I}}$ method showed the performance next to $\mathrm{M}_{2}$ method when interacted with $\mathrm{N}_{1}, \mathrm{~N}_{2}, \mathrm{~N}_{3}$, and $\mathrm{N}_{4}$. The minimum foliage yield was obtained from $\mathrm{N}_{0} \mathrm{M}_{1}$. This result corroborates with the report of Moniruzzaman et al. (2007) in kangkong. Based on foliage yield data, the treatment $\mathrm{N}_{3} \times \mathrm{M}_{2}$ (with $33 \%$ less $\mathrm{N}$ requirement compared to $\mathrm{N}_{4} \times \mathrm{M}_{2}$ ) seemed to be the best combination of $\mathrm{N}$ dose and method of its application for getting the maximum yield of the crop.

Relative efficiency of different methods of nitrogen application: Relative efficiency of different methods of nitrogen application was worked out and $\mathrm{M}_{2}$ was found to be highly superior to all the methods (Table 3). It was closely followed by $\mathrm{M}_{1}$ method in CS001, but in CS003, it is not very close. The least efficient method was $\mathrm{M}_{4}$ in both the genotypes. 
Table 3. Efficiency (\%) of different methods of nitrogen application.

\begin{tabular}{lllll}
\hline \multirow{2}{*}{ Method } & \multicolumn{3}{c}{ Genotype } \\
\cline { 3 - 4 } & & \multicolumn{2}{c}{ CS001 } & CS003 \\
\hline $\mathrm{M}_{1}$ & & 456.76 & 137.87 \\
$\mathrm{M}_{2}$ & & 467.03 & 212.69 \\
$\mathrm{M}_{3}$ & & 104.32 & 123.88 \\
$\mathrm{M}_{4}$ & & 100.00 & 100.00 \\
\hline \multirow{2}{*}{$\mathrm{M}_{1}=$ Entire N } & $\mathrm{M}_{2}=1 / 2 \mathrm{~N}$ as & $\mathrm{M}_{3}=1 / 2 \mathrm{~N}$ as basal & $\mathrm{M}_{4}=1 / 3 \mathrm{~N}$ at $20 \mathrm{DAS}, 1 / 3$ \\
& as basal & basal and $1 / 2 \mathrm{~N}$ & and $1 / 2 \mathrm{~N}$ at 30 DAS as & $\mathrm{N}$ at 30 DAS and $1 / 3 \mathrm{~N}$ at \\
& at 30 DAS as & foliar application & 40 DAS as foliar \\
& top dressing & & application
\end{tabular}

Table 4. Cost-return analysis of coriander production in different levels of nitrogen and its method of application.

\begin{tabular}{|c|c|c|c|c|c|c|}
\hline \multicolumn{2}{|c|}{ Treatment combination } & \multirow[b]{2}{*}{$\begin{array}{l}\text { Average } \\
\text { foliage } \\
\text { yield }(\mathrm{t} / \mathrm{ha})\end{array}$} & \multirow[b]{2}{*}{$\begin{array}{c}\text { Gross return } \\
(000 \\
\text { Tk./ha })\end{array}$} & \multirow[b]{2}{*}{$\begin{array}{c}\text { Cost of } \\
\text { cultivation } \\
(000 \mathrm{Tk} . / \mathrm{ha})\end{array}$} & \multirow{2}{*}{$\begin{array}{c}\text { Gross } \\
\text { margin } \\
(000 \text { Tk./ } \\
\text { ha })\end{array}$} & \multirow[b]{2}{*}{$\begin{array}{l}\text { Benefit- } \\
\text { cost ratio } \\
(\mathrm{BCR})\end{array}$} \\
\hline $\begin{array}{l}\text { Nitrogen } \\
\text { (N) }\end{array}$ & $\begin{array}{l}\text { Method } \\
\text { (M) }\end{array}$ & & & & & \\
\hline \multirow{4}{*}{$\mathrm{N}_{0}$} & $\mathrm{M}_{1}$ & 4.61 & 115.250 & 41.677 & 73.573 & 2.76 \\
\hline & $\mathrm{M}_{2}$ & 4.82 & 120.500 & 42.260 & 78.240 & 2.85 \\
\hline & $\mathrm{M}_{3}$ & 4.92 & 123.000 & 42.109 & 80.891 & 2.92 \\
\hline & $\mathrm{M}_{4}$ & 4.94 & 123.500 & 42.390 & 81.110 & 2.91 \\
\hline \multirow{4}{*}{$\mathrm{N}_{1}$} & $\mathrm{M}_{1}$ & 6.27 & 156.750 & 42.240 & 114.51 & 3.71 \\
\hline & $\mathrm{M}_{2}$ & 6.96 & 174.000 & 42.845 & 131.155 & 4.06 \\
\hline & $\mathrm{M}_{3}$ & 5.82 & 145.500 & 42.694 & 102.806 & 3.41 \\
\hline & $\mathrm{M}_{4}$ & 5.28 & 132.000 & 42.974 & 89.026 & 3.07 \\
\hline \multirow{4}{*}{$\mathrm{N}_{2}$} & $\mathrm{M}_{1}$ & 9.89 & 247.25 & 42.803 & 204.447 & 5.78 \\
\hline & $\mathrm{M}_{2}$ & 11.91 & 297.750 & 43.408 & 254.342 & 6.86 \\
\hline & $\mathrm{M}_{3}$ & 8.02 & 200.500 & 43.257 & 157.243 & 4.63 \\
\hline & $\mathrm{M}_{4}$ & 7.39 & 184.750 & 43.538 & 141.21 & 4.24 \\
\hline \multirow{4}{*}{$\mathrm{N}_{3}$} & $\mathrm{M}_{1}$ & 10.15 & 253.750 & 43.367 & 210.383 & 5.85 \\
\hline & $\mathrm{M}_{2}$ & 12.14 & 303.500 & 43.971 & 259.529 & 6.90 \\
\hline & $\mathrm{M}_{3}$ & 8.06 & 201.500 & 43.820 & 157.68 & 4.60 \\
\hline & $\mathrm{M}_{4}$ & 7.49 & 187.250 & 44.101 & 143.149 & 4.24 \\
\hline \multirow{4}{*}{$\mathrm{N}_{4}$} & $\mathrm{M}_{1}$ & 10.38 & 259.500 & 43.930 & 215.570 & 5.90 \\
\hline & $\mathrm{M}_{2}$ & 12.29 & 307.250 & 44.535 & 262.705 & 6.90 \\
\hline & $\mathrm{M}_{3}$ & 8.09 & 202.250 & 44.384 & 158.116 & 4.56 \\
\hline & $\mathrm{M}_{4}$ & 7.46 & 186.500 & 44.664 & 141.836 & 4.17 \\
\hline $\mathrm{N}_{0}=0 \mathrm{~kg} / \mathrm{ha}$ & \multicolumn{2}{|c|}{$\mathrm{N}_{1}=20 / \mathrm{kg}$ ha } & \multicolumn{2}{|c|}{$\mathrm{N}_{2}=40 \mathrm{~kg} / \mathrm{ha}$} & $\begin{array}{l}=60 \\
g / h a\end{array}$ & $\begin{array}{c}\mathrm{N}_{4}=80 \\
\mathrm{~kg} / \mathrm{ha}\end{array}$ \\
\hline $\begin{array}{c}\mathrm{M}_{1}=\text { Entire } \\
\mathrm{N} \text { as } \\
\text { basal }\end{array}$ & \multicolumn{2}{|c|}{$\begin{array}{l}\mathrm{M}_{2}=1 / 2 \mathrm{~N} \text { as } \\
\text { basal and } 1 / 2 \mathrm{~N} \\
\text { at } 30 \mathrm{DAS} \text { as } \\
\text { top dressing }\end{array}$} & \multicolumn{2}{|c|}{$\begin{array}{l}\mathrm{M}_{3}=1 / 2 \mathrm{~N} \text { as basal } \\
\text { and } 1 / 2 \mathrm{~N} \text { at } 30 \mathrm{DAS} \\
\text { as foliar application }\end{array}$} & \multicolumn{2}{|c|}{$\begin{array}{l}\mathrm{M}_{4}=1 / 3 \mathrm{~N} \text { at } 20 \mathrm{DAS}, 1 / 3 \\
\mathrm{~N} \text { at } 30 \mathrm{DAS} \text { and } 1 / 3 \mathrm{~N} \text { at } \\
40 \text { DAS as foliar } \\
\text { application }\end{array}$} \\
\hline
\end{tabular}

Produce (foliage): Tk. 25000.00/t (Tk. 25.00/kg); Urea: Tk. $26.08 \mathrm{~kg}-\mathrm{N}$ 
Economics: The maximum gross return (Tk. 307.25 thousand/ha) was obtained from $\mathrm{N}_{4} \times \mathrm{M}_{2}$ combination followed by $\mathrm{N}_{3} \times \mathrm{M}_{2}$ combination (Tk.303.5 thousand/ha) and $\mathrm{N}_{2} \times \mathrm{M}_{2}$ (Tk.297.75 thousand/ha) (Table 4). The highest gross margin was also recorded from $\mathrm{N}_{4} \times \mathrm{M}_{4}$ combination (Tk. 262.705 thousand/ha) followed by $\mathrm{N}_{3} \times \mathrm{M}_{2}$ combination (Tk. 259.529 thousand/ha) and $\mathrm{N}_{2} \times \mathrm{M}_{2}$ (Tk.254.342 thousand/ha). Minimum gross margin was recorded in $\mathrm{N}_{0} \times \mathrm{M}_{1}$ combination. The highest benefit-cost ratio (6.90) was recorded from both $N_{4} \times M_{2}$ and $N_{3} \times M_{2}$ combinations and the lowest for the same from $N_{0} \times M_{1}$. Although $\mathrm{N}_{4} \times \mathrm{M}_{2}$ gave higher gross margin than $\mathrm{N}_{3} \times \mathrm{M}_{2}$, both the combinations gave the same BCR (6.90). The cost of cultivation in $\mathrm{N}_{4} \times \mathrm{M}_{2}$ was Tk. 44.535 thousand/ha while it was Tk. 43.971 thousand/ha, in $\mathrm{N}_{3} \times \mathrm{M}_{2}$. Since the $\mathrm{N}_{3} \times \mathrm{M}_{2}$ incurred less cost compared to $\mathrm{N}_{4} \times \mathrm{M}_{2}, \mathrm{~N}_{3} \times \mathrm{M}_{2}$ was the most profitable combination for foliage yield of coriander.

Based on the results, it could be concluded that coriander should be cultivated with $60 \mathrm{~kg} \mathrm{~N} / \mathrm{ha}$ applied one- half as basal and the rest one-half at 30 days after sowing for maximum yield of foliage with the highest economic benefit for the genotypes CSO01 and CSO03.

\section{References}

BARI (Bangladesh Agricultural Research Institute). 2010. Annual Research Report for 2009-2010. On-Farm Res. Divn., Bangladesh Agril. Res. Inst. (BARI), Gazipur. Pp. 107-108.

Badgujar, C. D., K. E. Lawande, P. N. Kale and K. G. Choudhuri.1987. Response of coriander to foliar application of urea. Current Res. Rep. 3(2): 118-119.

BARC. 2005. Fertilizer Recommendation Guide-2005. Bangladesh Agricultural Research Council (BARC), Farmgate, New Airport Road Dhaka-1215. Pp. 39-42.

Brady, N. C. 1990. The Nature and Properties of Soils. $10^{\text {th }}$ ed. Macmillan Pub. Co. New York. P. 315

Dhanasekar, D., M. Vijayakumar, V. A. Sathiyamurthy and V. Sankar. 2000. Studies on growth pattern in coriander to fix the optimum stage of harvest for green yield. South Indian Hort. 48(1-6): 157-159.

http://www.indianspices.com/html/spices spfarm cori.html.

Moniruzzaman, M and M. R. Islam. 2006. Effects of nitrogen level and foliage cuttings on the yield and profiability of spinach in hilly regions. Bangladesh J. Agril. Res. 31(2): 199-206.

Moniruzzaman, M, M. S. Islam, M. M. Hossain, T. Hossain and M. G. Miah. 2009. Effects of shade and nitrogen levels on quality Bangladhonia production. Bangladesh J. Agril. Res. 34(2): 205-213.

Moniruzzaman, M., M. R. Islam and S. N. Mozumder. 2005. Response of lettuce cultivars to split application of nitrogen in Rangamati. Bangladesh J. Agril. Res. 30(2): 203-209. 
Moniruzzaman, M., M. R. Islam and S. N. Mozumder. 2007. Response of kangkong to various levels and methods of nitrogen application. Bangladesh J. Agril. Res. 32(2): 205-2213.

Oliveira, A. P. de, de S. Paiva-Sobrinho, J. K.A. Barbosa, C. I. Ramalho, A. L. P. Oliveira, Oliveira A. P. De and S.de-Paiva Sobrinho. 2003. Rendimento de coentro cultivado com doses crescentes de $\mathrm{N}$ (Yield of coriander cultivated with increasing nitrogen levels). Hortic. Bras. 21(1): 81-83.

Rajput, C. B. S. and K. P. Singh. 1975. Response of cauliflower cultivar snowball-16 to various levels and methods of nitrogen application. Bangladesh Hort. 3(1): 23-30.

Ullah, M. H., M. M. U. Chowdhury, S. M. Nabi, Sabera Sultana and N. K. Halder. 1999. A study on yield potentiality of cabbage as influenced by NPK and S fertilization. Bangladesh J. Agril. Res. 24 (4): 637-643. 